\title{
Wpływ metody wyznaczania parametrów wytrzymałościowych gruntów na wyniki analiz stateczności skarp i zboczy
}

\author{
Robert Kaczmarczyk ${ }^{1}$, Jakub Czurczak ${ }^{1}$
}
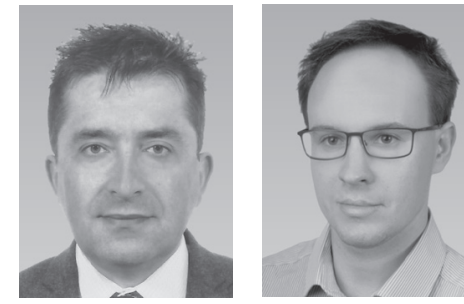

R. Kaczmarczyk

J. Czurczak

Impact of the method of determination of soil strength parameters on the results of slope stability analyses. Prz. Geol., 68: 577-583; doi: 10.7306/2020.22

A b s tract. The basic assumptions determining the methodology for testing soil strength parameters have been known for almost 250 years (Coulomb, 1773). Nevertheless, obtaining reliable and unambiguous parameter values for calculations is still a difficult problem.

The main problem results from the fact that soil strength parameters are not a material constant. This means that the values of the angle of internal friction and soil coherence are dependent on the research methodology used. The article presents the impact of the method of determination of soil strength parameters on the assessment of slope stability. The earlier literature recommends adapting the method of testing samples as much as possible to real conditions. This allows the geologist to have some freedom in choosing the research methodology. The PN-EN 1997-2: 2008 standard puts more emphasis on a uniform test methodology. In the interpretation of Eurocode 7, due to the need to determine accurately effective stresses, "only strength tests of soils completely saturated with water or dry soils are considered". Stability analyses performed for a small, still active landslide in Kojszówka have shown that the use of only effective parameters for slope analyses may not be fully reliable.

Keywords: landslide, soil strength parameters, slope stability analysis

Ciągły rozwój zaawansowanych programów służących do analiz stateczności skarp i zboczy, pozwala uzyskać szerokie i precyzyjne wyniki. Modelowanie numeryczne stwarza niespotykane wcześniej możliwości odwzorowania warunków geologiczno-inżynierskich. Należy jednak pamiętać, że w ocenie zagrożeń osuwiskowych wiarygodne wyniki analiz wymagają nie tylko zastosowania nowoczesnych technik obliczeniowych lecz także użycia do analiz miarodajnych i rzeczywistych wartości parametrów wytrzymałościowych.

Zasadniczy problem wynika z faktu, że parametry wytrzymałościowe gruntów nie są stałą materiałową. Oznacza to, że wartości kąta tarcia wewnętrznego i spójności zależą nie tylko od właściwości fizycznych próbek oraz ich genezy i litologii, lecz także od zastosowanej metodyki ich oznaczeń. Może prowadzić to do sytuacji, w której parametry wytrzymałościowe gruntów oznaczane według różnych norm, a w konsekwencji wyniki obliczeń inżynierskich uzyskane z tych oznaczeń, mogą się od siebie znacząco różnić. W szczególny sposób problem ten dotyczy wyników analiz stateczności skarp i zboczy. W praktyce już kilkunastoprocentowe różnice w wartościach wskaźnika stateczności zbocza mogą zaważyć na wielomilionowych wydatkach. Decyzja o zabezpieczeniu zbocza lub o konieczności wysiedlenia mieszkańców ze strefy zagrożeń osuwiskowych musi być podjęta na podstawie rzetelnych i wiarygodnych danych. Jednak inżynierskie (matematyczne) opisanie środowiska przyrodniczego nie jest łatwe, niekiedy nawet dyskusyjne. W artykule podjęto próbę określenia wpływu metodyki oznaczeń parametrów wytrzymałościowych na bezpieczeństwo projektowania $\mathrm{w}$ geotechnice.

\section{METODYKA OZNACZEŃ PARAMETRÓW WYTRZYMALOŚCI NA ŚCINANIE}

Historyczną, lecz stosowaną do dzisiaj, formułą określającą wynik ścinania gruntu jest wzór Coulomba z 1773 r.

$$
\tau=\sigma_{n} \operatorname{tg} \Phi+c
$$

W założeniu Coulomba wytrzymałość jest funkcją naprężenia normalnego $\left(\sigma_{n}\right)$, kąta tarcia wewnętrznego $(\Phi)$ oraz spójności (kohezji) (c).

Sformułowana 150 lat później przez Terzaghiego (1923, 1936) zasada naprężeń efektywnych określa, że wytrzymałość na ścinanie nie jest funkcją całkowitego naprężenia normalnego, lecz różnicy między całkowitym naprężeniem normalnym a ciśnieniem wody w porach.

$$
\tau=\left(\sigma_{n}-u\right) \operatorname{tg} \Phi^{\prime}+c^{\prime}
$$

Zatem aby określić parametry efektywne, sposób badania próbek powinien być tak dobrany, aby w trakcie badania nie doszło do przyrostu ciśnienia wody w porach gruntu lub wartość wzrostu ciśnienia podczas badania była mierzona.

Metodyka badań próbek oparta na starszej literaturze (Wiłun, 1976, 2013; Lambe, Whitman, 1977; Kaczyński, 1984; Glazer, 1985; ) zaleca możliwie maksymalne dostosowanie sposobu obciążania próbek modelowych do warunków zmian naprężeń w warunkach rzeczywistych zarówno tych występujących obecnie, jak i możliwych do wystąpienia w przyszłości.

\footnotetext{
${ }^{1}$ AGH Akademia Górniczo-Hutnicza, Wydział Geologii, Geofizyki i Ochrony Środowiska, al. A. Mickiewicza 30, 30-059 Kraków; rkaczmar@op.pl; kubusp51@gmail.com
} 
W zależności od prędkości przyrastania obciążenia próbek i możliwości odpływu wód porowych, uzyskuje się parametry efektywne (badania na próbkach po konsolidacji i przy powolnym narastaniu naprężeń ścinających) lub całkowite, uzyskiwane w warunkach, gdy ciśnienie wody wywołane wzrostem obciążeń nie zdąży się rozproszyć. Wybór metody badań powinien być dostosowany do konkretnego zadania inżynierskiego.

Parametry całkowite (pozorne) zaleca się przyjmować, gdy projektujemy obiekty, dla których w fazie budowy i eksploatacji może nastąpić szybki przyrost obciążeń na podłoże. Według Pieczyraka (2014) są to budowle realizowane krócej niż 3 miesiące lub obiekty, dla których obciążenia zmienne przekraczają $50 \%$ obciążeń całkowitych. Pisarczyk (1998) zaleca badania bez konsolidacji dla budowli posadowionych na podłożu małoprzepuszczalnym o obciążeniu użytkowym przekraczającym $70 \%$ całkowitego. W pozostałych przypadkach zaleca się przyjmować parametry efektywne.

W aparacie trójosiowego ściskania, w zależności od warunków konsolidacji próbek (izotropowa, anizotropowa, bez konsolidacji), warunków odpływu, szybkości i kierunku zmian naprężeń głównych oraz zmian ciśnienia wód porowych, podczas obciążania próbek można uzyskać kilka rożnych wartości parametrów wytrzymałościowych.

Najczęściej stosuje się jednią z trzech metod:

- badanie bez konsolidacji i odsączania (UU - unconsolidated undrained); zawartość wody w próbce utrzymywana jest przez cały czas doświadczenia bez zmian, metoda ta jest również nazywana $\mathrm{Q}$ od słowa quick;

- badanie z konsolidacją, bez drenażu (CU - consolidated undrained); próbka konsolidowana jest przy obciążeniu izotropowym $\sigma_{3}$, lecz w czasie badania odsączanie wody jest uniemożliwione. Podczas badania w trakcie wzrostu obciążenia następuje pomiar różnicy naprężeń (całkowitych) $\sigma_{1}-\sigma_{3}$ oraz ciśnienia wody w porach gruntu $u$. Naprężanie efektywne oblicza się z różnic między naprężeniem normalnym a ciśnieniem wody w porach gruntu $\sigma^{\prime}=\sigma-u$;

- badanie z drenażem (CD - consolidated drained); próbkę konsoliduje się jak w badaniach typu $\mathrm{CU}$, jednak po przyłożeniu obciążenia odpowiadającego różnicy naprężeń (efektywnych) $\sigma_{1}^{\prime}-\sigma_{3}^{\prime}$, odpływ wody jest nadal możliwy, a przyrost naprężeń powinien być na tyle powolny, aby nie występowało ciśnienie wody w porach $u \sim 0$. Metoda ta jest również nazywana $\mathrm{S}$ od słowa slow (Pisarczyk, 2015).

Metodyka badań wytrzymałości gruntów oparta o wskazania normy Eurokod 7 (PN-EN 1997-2: 2008) zakłada, że sposób konsolidacji i obciążania próbek powinien być tak dobrany, aby uzyskać efektywne wartości kąta tarcia wewnętrznego i spójności.

Według PN-EN 1997-2: 2008 Eurokod 7 badania w aparacie skrzynkowym (aparacie bezpośredniego ścinania) lub aparacie pierścieniowym powinny być wykonywane $\mathrm{z}$ odpływem wód porowych. Podczas badania należy unikać ujemnych lub dodatnich wartości ciśnienia wody w porach, spowodowanych ścinaniem, ponieważ nie mogą być one pomierzone i uwzględniane przy interpretacji wyników badań. $W$ celu zachowania warunków z odptywem, prędkość ścinania powinna być dostatecznie mata, aby mogło nastapić rozproszenie ciśnienia porowego.

$W$ wyniku badania bezpośredniego ścinania w aparacie skrzynkowym otrzymuje się wytrzymałość z odptywem.
Wielkościami sa efektywny kąt tarcia wewnętrznego i efektywna spójność. Wartości te moga być wykorzystywane $w$ analizach stateczności.

W interpretacji Eurokodu 7 badanie bez konsolidacji i odsączania (w aparacie trójosiowego ściskania) pozwala oznaczyć jedynie wytrzymałość na ścinanie bez odpływu $c_{u}$. W tego typu badaniu norma zakłada, że $\mathrm{w}$ warunkach „bez odpływu” naprężenia normalne działające na płaszczyznę ścinania nie mają wpływu na wytrzymałość gruntu na ścinanie. W teorii oznacza to całkowity zanik oporu tarcia wewnętrznego w gruncie $\left(\Phi^{\prime}=0\right)$. W ujęciu praktycznym nawet $\mathrm{w}$ warunkach pełnego nasycenia $(\mathrm{Sr}=1)$ stan taki jest mało prawdopodobny.

Autorzy normy Eurokod 7 podkreślają, że rozpatrywane sa tylko badania wytrzymałościowe gruntów całkowicie nasyconych woda albo gruntów suchych. $\mathrm{Z}$ uwagi na brak możliwości precyzyjnego pomiaru ciśnienia wód porowych gruntów nienasyconych, metodyka badań zaproponowana w normie jest słuszna zarówno $\mathrm{z}$ teoretycznego, jak i matematycznego punktu widzenia, niemniej wyniki badań uzyskane z tego typu badań nie muszą odzwierciedlać zachowania gruntu w warunkach rzeczywistych. Problem ten w sposób szczególny dotyczy gruntów występujących w koluwiach osuwisk, które w wyniku przemieszczeń są nieskonsolidowane i nienasycone.

Autorzy normy Eurokod 7 zaznaczają, że badania jednoosiowego ściskania oraz badania trójosiowego ściskania bez wstępnej konsolidacji i bez odptywu, nie musza przedstawiać (odzwierciedlać) wytrzymałości gruntu na ścinanie $w$ warunkach in situ.

W rozwiązaniach praktycznych, tj. analizach stateczności osuwisk rzeczywistych, zastosowanie zarówno parametrów efektywnych, jak i parametru wytrzymałości bez odpływu $c_{u}$, budzi wątpliwości ze względu na skrajne, niemal zero-jedynkowe wyniki.

W badaniach z konsolidacją z odpływem, niezależnie od rodzaju gruntu oraz stanu jego konsystencji, uzyskuje się bardzo wysokie wartości kąta tarcia wewnętrznego przy stosunkowo niskich wartościach spójności. W badaniach bez odplywu kąt tarcia wewnętrznego dla tych samych próbek ma wartość zero, brak jest możliwości uzyskania wyników pośrednich.

Wyniki badań zamieszczone w tabeli 1 wskazują, że parametry efektywne gruntów, wyznaczone według metodyki proponowanej przez normę Eurokod, charakteryzują się kilkukrotnie wyższymi wartościami kąta tarcia wewnętrznego i w niektórych przypadkach nawet kilkunastokrotnie mniejszą wartością spójności od parametrów pozornych, wyznaczonych z naprężeń całkowitych. Ponadto w przypadku obliczenia parametrów wytrzymałościowych gruntów metodą proponowaną przez Eurokod 7, początkowy stan konsystencji próbek nie wpływa w sposób istotny na uzyskane wartości. Duża różnica wyników w przypadku gruntów słabych może być przyczyną kontrowersji. Przy założeniu, że mamy do czynienia z płytkim osuwiskiem gruntowym, w którym występuje strefa uplastycznienia gruntów, przyjęcie do analiz stateczności wyników efektywnych, które są sumarycznie niemal dwukrotnie wyższe niż parametry gruntu bez konsolidacji, może powodować sytuacje, że pojawi się błąd związany z zawyżeniem parametrów. Przyjęcie słabszych parametrów bez konsolidacji nie wyklucza wystąpienia błędu, natomiast znajdzie się on po stronie bezpiecznej. 
Tab. 1. Wartości parametrów wytrzymałościowych efektywnych i pozornych dla wybranych próbek Table 1. Values of effective and apparent strength parameters for selected samples

\begin{tabular}{|c|c|c|c|c|c|c|c|}
\hline \multirow[b]{2}{*}{$\begin{array}{l}\text { Lokalizacja } \\
\text { Location }\end{array}$} & \multirow[b]{2}{*}{$\begin{array}{l}\text { Rodzaj } \\
\text { gruntu } \\
\text { Type of soil }\end{array}$} & \multirow[b]{2}{*}{$\begin{array}{l}\text { Stan konsystencji } \\
\text { Consistency }\end{array}$} & \multirow{2}{*}{$\begin{array}{c}\text { Stopień } \\
\text { plastyczności } \\
\text { Liquidity } \\
\text { index } \\
\mathbf{I}_{\mathrm{L}}[-]\end{array}$} & \multicolumn{2}{|c|}{$\begin{array}{l}\text { Parametry efektywne } \\
\text { Effective parameters }\end{array}$} & \multicolumn{2}{|c|}{$\begin{array}{l}\text { Parametry pozorne } \\
\text { Apparent parameters }\end{array}$} \\
\hline & & & & $\begin{array}{c}\text { Kąt tarcia wewnętrznego } \\
\text { Friction angle } \\
\phi_{\mathrm{u}}\left[^{\circ}\right]\end{array}$ & $\begin{array}{l}\text { Spójność } \\
\text { Cohesion } \\
\mathrm{c}_{\mathrm{u}}[\mathrm{kPa}]\end{array}$ & $\begin{array}{c}\text { Kąt tarcia wewnętrznego } \\
\text { Friction angle } \\
\left.\phi_{\mathrm{u}} \mathrm{I}^{\circ}\right]\end{array}$ & $\begin{array}{l}\text { Spójność } \\
\text { Cohesion } \\
\mathrm{c}_{\mathrm{u}}[\mathrm{kPa}]\end{array}$ \\
\hline \multirow{3}{*}{$\begin{array}{l}\text { Kraków, } \\
\text { os. Ruczaj }\end{array}$} & \multirow{3}{*}{$\begin{array}{l}\text { ił pylasty } \\
\text { siCl }\end{array}$} & tpl/pl / stiff/firm & 0,25 & 24,9 & 6,4 & 12,6 & 56,2 \\
\hline & & $\mathrm{pzw} / \mathrm{tpl} /$ very stiff/stiff & 0,00 & 25,9 & 12,3 & 16,7 & 77,0 \\
\hline & & pzw / very stiff & $-0,20$ & 26,8 & 7,3 & 18,1 & 146,5 \\
\hline \multirow[t]{3}{*}{ Ochojno } & \multirow{3}{*}{$\begin{array}{c}\text { glina } \\
\text { zwięzła } \\
\text { sasiCl }\end{array}$} & $\mathrm{mpl} /$ soft & 0,66 & 29,2 & 3,1 & 6,5 & 11,1 \\
\hline & & $\mathrm{pl} /$ firm & 0,47 & 30,3 & 2,2 & 10,8 & 19,7 \\
\hline & & tpl / stiff & 0,13 & 27,1 & 5,8 & 18,2 & 53,9 \\
\hline
\end{tabular}

\section{WYNIKI ORAZ ANALIZA BADAŃ}

Na potrzeby lepszego zobrazowania przedmiotowego problemu wybrano niewielkie (0,072 ha) osuwisko zlokalizowane w miejscowości Kojszówka w gminie Maków Podhalański w powiecie suskim w województwie małopolskim. Zdjęcie obiektu badań wraz z lokalizacją na konturowej mapie Polski zostało przedstawione na rycinie 1 . Osuwisko to wybrano z uwagi na stosunkowo mało skomplikowaną budowę geologiczną, co pozwoliło ograniczyć ilość czynników wpływających na uzyskane wyniki.

Osuwisko to powstało pod koniec 2017 r. po kilkudniowym okresie wzmożonych opadów w wyniku infiltra- cji wód opadowych. Dodatkowym czynnikiem, który doprowadził do utraty stateczności było dociążanie stoku przez cyklicznie powiększany nasyp antropogeniczny. Na osuwisku i w jego otoczeniu wykonano wiercenia z poborem próbek o nienaruszonej strukturze. Wyniki badań laboratoryjnych z podziałem na warstwy geotechniczne przedstawiono w tabeli 2 .

Oznaczenia parametrów fizyczno-mechanicznych gruntów wykonano zgodnie z normą PN-EN ISO 14688 oraz PN-EN 1997-2: 2008. Wytrzymałość na ścinanie określono w aparacie bezpośredniego ścinania firmy Wykeham Farrance model 27-WF25510. Wartości kąta tarcia wewnętrznego i spójności dla próbek pobranych

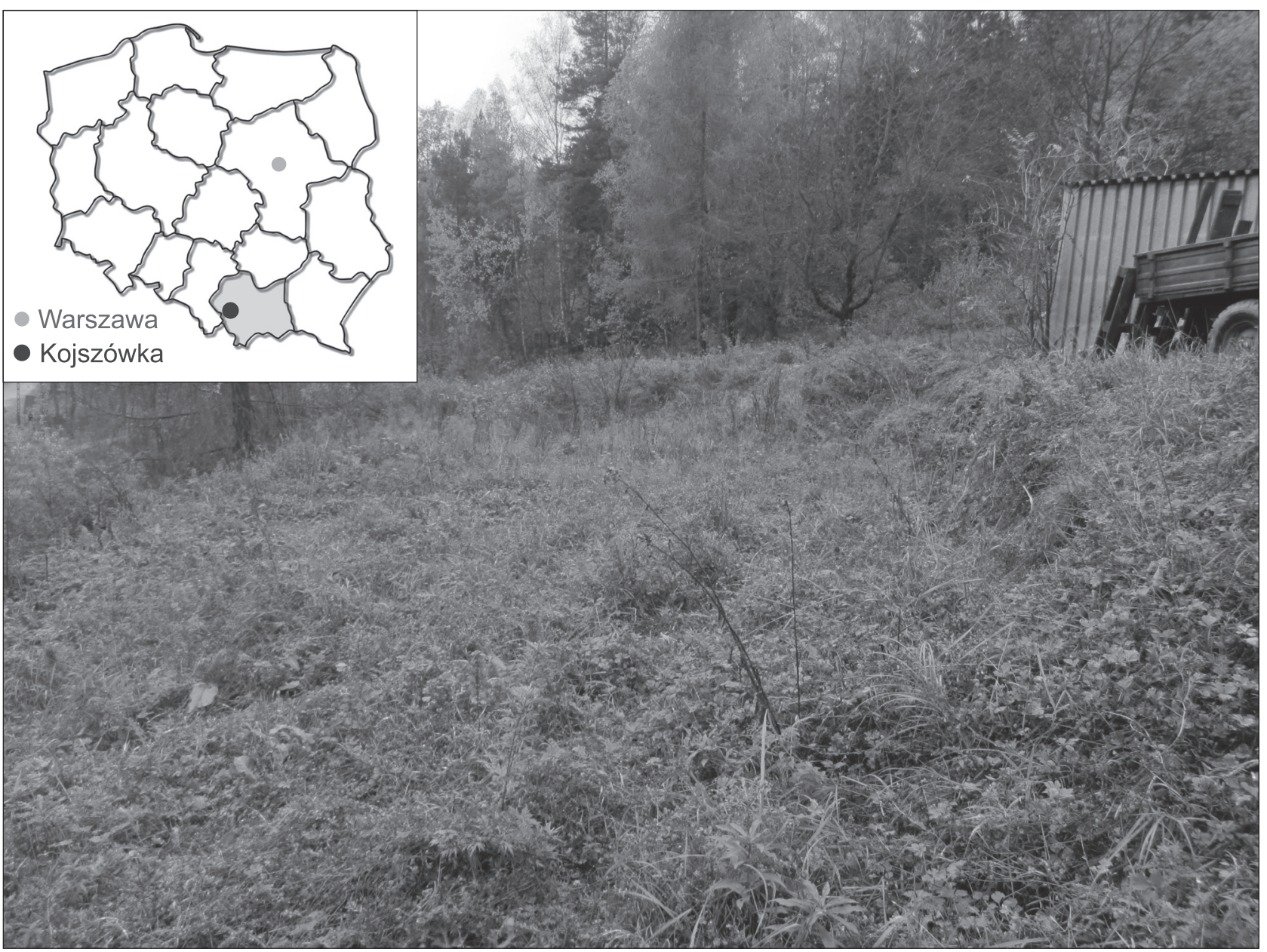

Ryc. 1. Zdjęcie górnej części osuwiska zlokalizowanego w Kojszówce oraz lokalizacja miejsca badań na mapie Polski. Fot. J. Czurczak Fig. 1. Photo of the upper part of landslide located in Kojszówka and the research site location. Photo by J. Czurczak 
Tab. 2. Wyniki badań laboratoryjnych próbek z warstw geotechnicznych

Table 2. Results of laboratory tests of samples from geotechnical layers

\begin{tabular}{|c|c|c|c|c|c|c|}
\hline 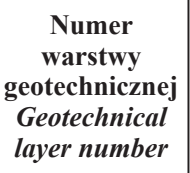 & $\begin{array}{c}\text { Rodzaj gruntu } \\
\text { PN-EN ISO } 14688 \\
\text { Type of soil } \\
\text { PN-EN ISO } 14688\end{array}$ & $\begin{array}{c}\text { Stopień } \\
\text { plastyczności } \\
\text { Liquidity } \\
\text { index } \\
\mathrm{I}_{\mathrm{L}}[-]\end{array}$ & $\begin{array}{c}\text { Kąt tarcia } \\
\text { wewnętrznego } \\
\text { Friction angle } \\
\phi_{\mathrm{u}}\left[^{\circ}\right]\end{array}$ & $\begin{array}{c}\text { Spójność } \\
\text { Cohesion } \\
\mathrm{c}_{\mathrm{u}}[\mathrm{kPa}]\end{array}$ & $\begin{array}{c}\text { Gęstość } \\
\text { objętościowa } \\
\text { Volumetric } \\
\text { density } \\
\rho\left[\mathrm{Mg} / \mathbf{m}^{3}\right]\end{array}$ & $\begin{array}{l}\text { Wskaźnik } \\
\text { porowatości } \\
\text { Porosity } \\
\text { index } \\
\text { e [-] }\end{array}$ \\
\hline $\mathrm{I}$ & nasyp / embankment & - & 9,0 & 11,0 & - & \\
\hline II & glina piaszczysta / saclSi & 0,12 & 18,0 & 30,0 & 2,17 & 0,46 \\
\hline III & glina zwięzła ze żwirem / clSior, saclSi & $0,29-0,41$ & 12,0 & 12,0 & 2,04 & 0,71 \\
\hline IV & zwietrzelina piaskowca/zwietrzelina łupka / grsaCl & 0,01 & 21,0 & 50,0 & 2,12 & 0,50 \\
\hline $\mathrm{V}$ & $\mathrm{Wp} / \mathrm{Wcl} *$ & $-0,50$ & 22,0 & 120,0 & 2,23 & 0,46 \\
\hline A & $\begin{array}{l}\text { koluwium - badanie bez konsolidacji / } \\
\text { colluvium - no consolidation }\end{array}$ & 0,69 & 6,2 & 8,3 & 2,01 & 0,70 \\
\hline B & $\begin{array}{l}\text { koluwium - badanie z konsolidacją } 100 \mathrm{kPa} \text { przez } 24 \\
\text { godziny / colluvium - consolidation } 100 \mathrm{kPa} \text { for } 24 \mathrm{~h}\end{array}$ & 0,00 & 27,0 & 28,1 & 2,16 & 0,50 \\
\hline C & $\begin{array}{l}\text { koluwium - badanie z konsolidacją } 200 \mathrm{kPa} \text { przez } 24 \\
\text { godziny / colluvium - consolidation } 200 \mathrm{kPa} \text { for } 24 \mathrm{~h}\end{array}$ & $-0,06$ & 31,1 & 50,0 & 2,18 & 0,47 \\
\hline
\end{tabular}

* V warstwa geotechniczna jest zbudowana z klasycznych utworów fliszowych, tj. łupków ilastych i piaskowców zwietrzałych w jej stropowej części.

*V geotechnical layer is composed of classic Carpathian deposits such as shales and sandstones.

z koluwium osuwiska oznaczono trzema metodami, których celem było określenie wpływu czasu konsolidacji oraz wielkości naprężenia konsolidacyjnego na uzyskane wyniki.

Dla każdej z metod wykonano po 2 oznaczenia przy naprężeniach normalnych $25,50,75$ oraz $100 \mathrm{kPa}$. W sumie ścięto 24 próbki $(3 \times 8)$. Wyniki badań oznaczeń kąta tarcia wewnętrznego oraz spójności przedstawiono na rycinie 2 .

Próbki pobrane $\mathrm{z}$ koluwium osuwiska były podatne na konsolidacje. Na podstawie wytycznych z PKN-CEN ISO/TS 17892-10 określono, że prędkość ścinania $0,1 \mathrm{~mm} / \mathrm{min}$ jest dostatecznie mała żeby nie wystąpił przyrost ciśnienia w porach gruntu. Dla gruntów bardzo słabo przepuszczalnych prędkość przemieszczeń powinna być mniejsza, np. 0,01 lub $0,001 \mathrm{~mm} / \mathrm{min}$.

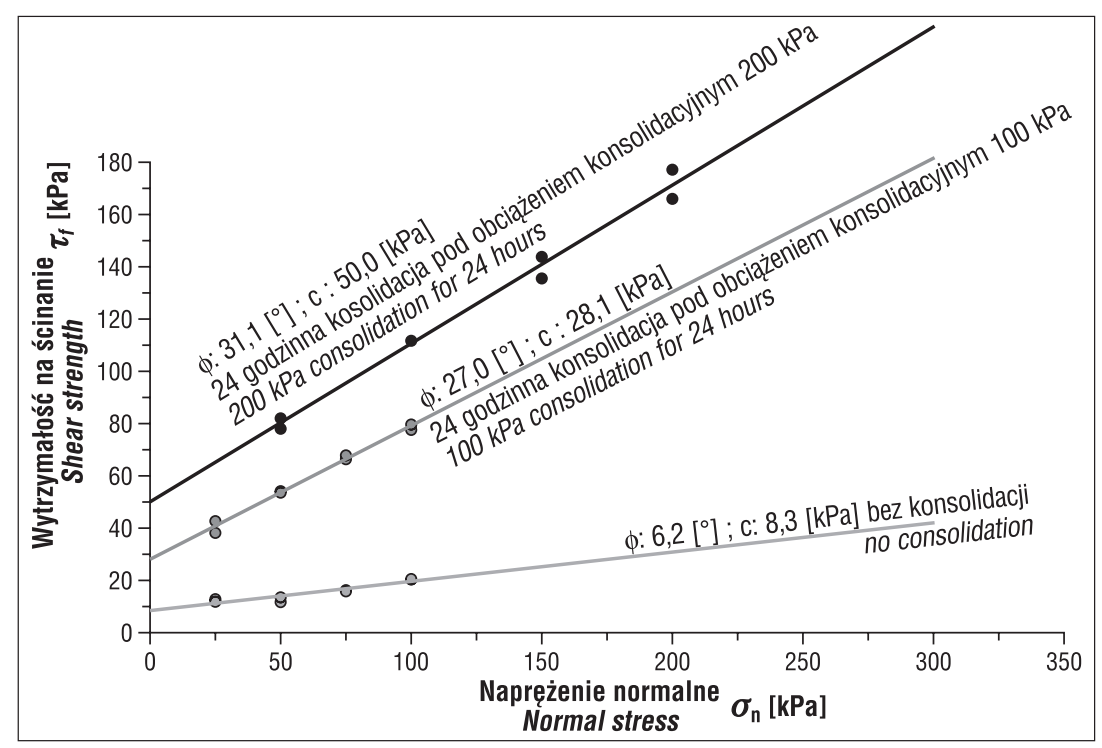

Ryc. 2. Linie wytrzymałości na ścinanie dla próbek badanych bez konsolidacji oraz po 24 godzinnej konsolidacji pod obciążeniem konsolidacyjnym 100 i $200 \mathrm{kPa}$

Fig. 2. Shear strength lines for samples tested without consolidation and after 24 hours of 100 and $200 \mathrm{kPa}$ consolidation
W metodzie A - próbki były ścinane bez wcześniejszej konsolidacji przy prędkości $1 \mathrm{~mm} / \mathrm{min}$.

W metodzie B - próbki były ścinane po 24 godzinnej konsolidacji przy naprężeniu konsolidacyjnym równym $100 \mathrm{kPa}$, przy prędkości przesuwu $0,1 \mathrm{~mm} / \mathrm{min}$.

W metodzie $\mathrm{C}$ - próbki były ścinane po 24 godzinnej konsolidacji przy naprężeniu konsolidacyjnym równym $200 \mathrm{kPa}$, przy prędkości przesuwu $0,1 \mathrm{~mm} / \mathrm{min}$.

Dla próbek oznaczono gęstość objętościową (po konsolidacji) oraz stopień plastyczności (po zakończeniu badania). Wyniki wszystkich badań przedstawiono w tabeli 2 .

Obliczenia stateczności przedmiotowego osuwiska przeprowadzono za pomocą programu GEO5 Stateczność zbocza. Stateczność sprawdzono metodami Bishopa, Felleniusa/Pettersona, Spencera, Janbu oraz Morgensterna-Price'a. Obliczenia wykonano dla kołowej powierzchni poślizgu po jej optymalizacji, tj. dla powierzchni najbardziej niekorzystnego stosunku sił utrzymujących do zsuwających. Jako najbardziej reprezentacyjna według autorów została wybrana metoda Bishopa, której wyniki wykorzystano na potrzeby tego artykułu.

Po stworzeniu modelu obliczeniowego wykonano szereg obliczeń stateczności dla parametrów uzyskanych z metody A, B i C. Na rycinie 3 przedstawiono model obliczeniowy, natomiast na rycinach 4-6 - wyniki analiz stateczności.

\section{WNIOSKI I ZALECENIA}

Wyniki badań wskazują, że zastosowanie do analiz zboczy wyłącznie parametrów efektywnych może nie być w pełni miarodajne. W zależności od metody oznaczania parametrów wytrzymałościowych, dla tych samych próbek możemy uzyskać różne wartości kąta tarcia wewnętrznego i spójności. 


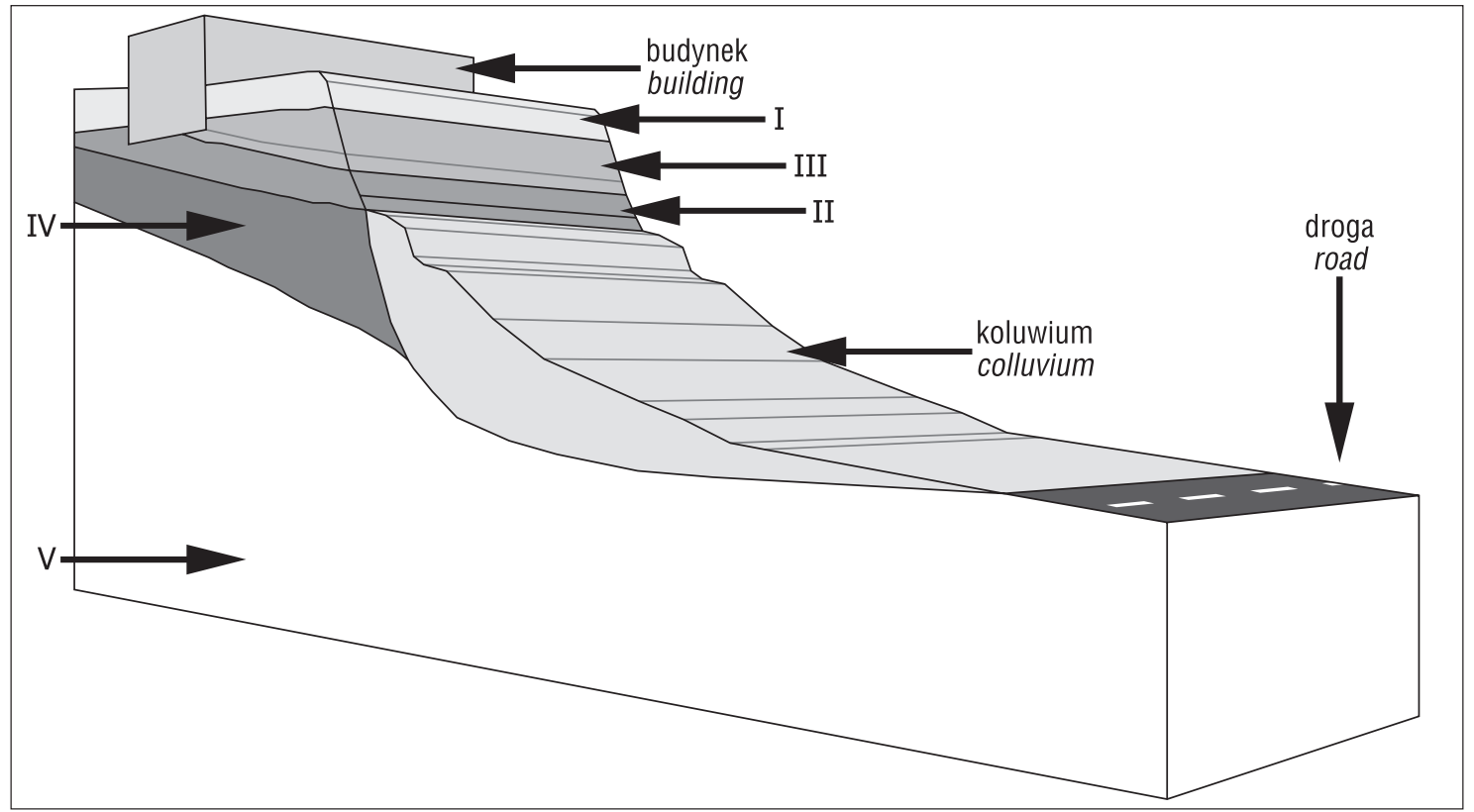

Ryc. 3. Model poglądowy osuwiska w Kojszówce. Cyframi I-V zaznaczono numery warstw geotechnicznych Fig. 3. Illustrative model of landslide in Kojszówka. Geotechnical layers are marked with numbers I-V

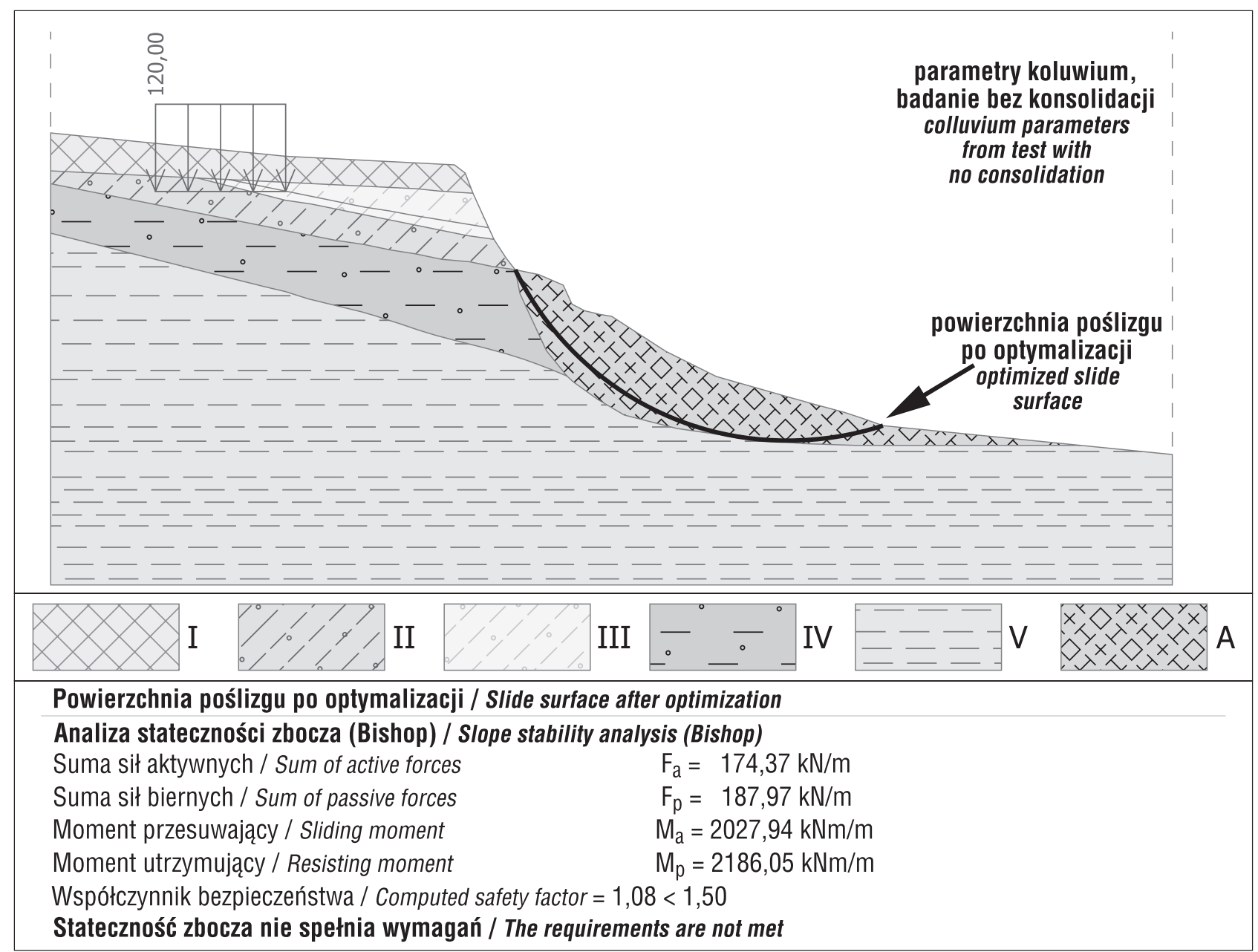

Ryc. 4. Analiza statecznści osuwiska w Kojszówce - parametry koluwium wyznaczone bez wcześniejszej konsolidacji. Cyframi I-V zaznaczono numery warstw geotechnicznych

Fig. 4. Slope stability analysis of landslide in Kojszówka - colluvium parameters from test with no consolidation. Geotechnical layers are marked with numbers I-V 


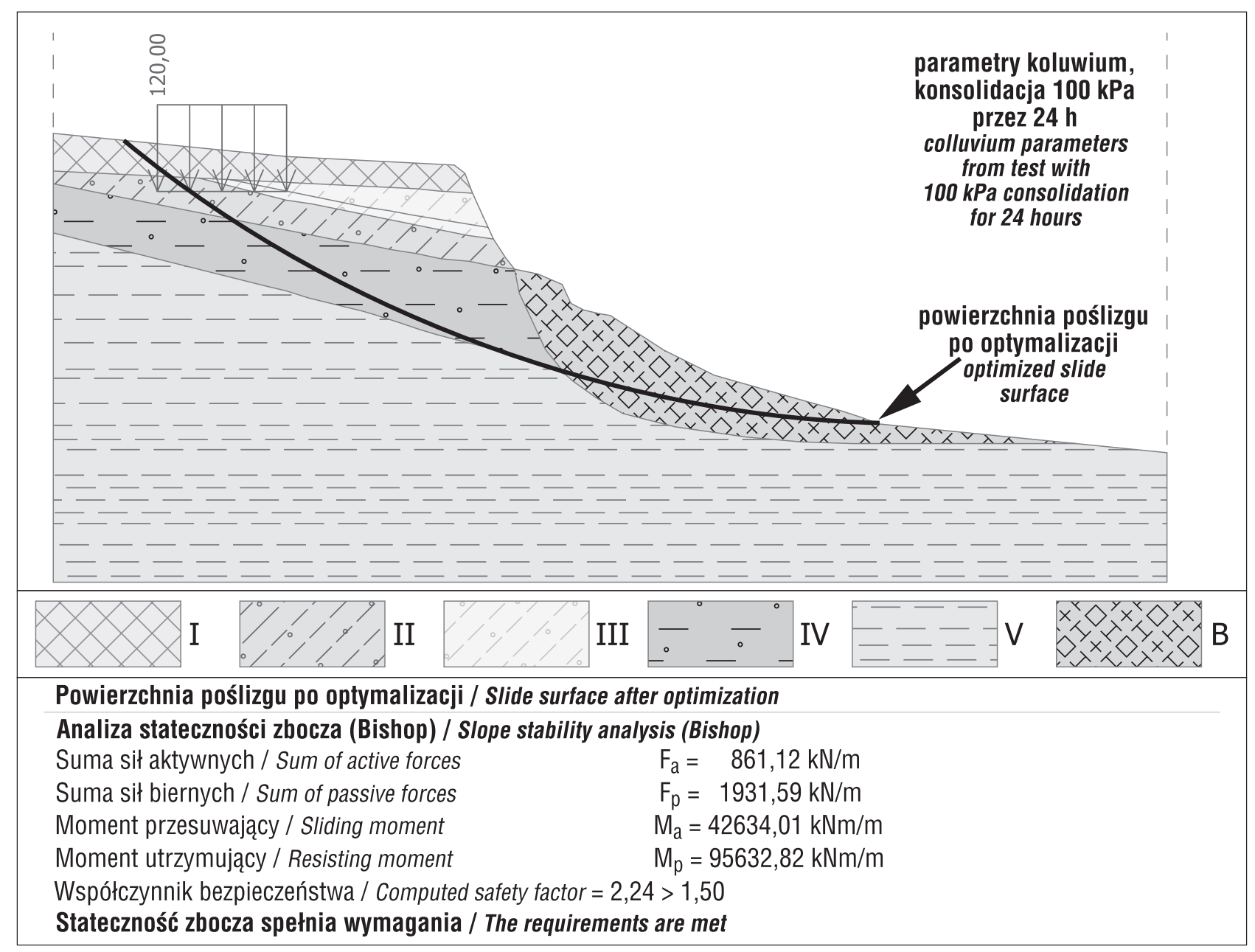

Ryc. 5. Analiza statecznści osuwiska w Kojszówce - parametry koluwium wyznaczone po 24-godzinnej konsolidacji przy naprężeniu konsolidacyjnym $100 \mathrm{kPa}$. Cyframi I-V zaznaczono numery warstw geotechnicznych

Fig. 5. Slope stability analysis of landslide in Kojszówka - colluvium parameters from test with $100 \mathrm{kPa}$ consolidation for 24 hours. Geotechnical layers are marked with numbers I-V

W konsekwencji wyniki analiz stateczności mogą się w znacznym stopniu od siebie różnić. W przypadku analizowanego osuwiska różnice były bardzo duże, wahały od 1,08 dla parametrów bez konsolidacji (zbocze na granicy stateczności) do 2,52 po konsolidacji przy obciążeniu 200 $\mathrm{kPa}, \mathrm{w}$ tym przypadku suma sił utrzymujących jest ponad dwuipółkrotnie wyższa niż zsuwających.

$\mathrm{Na}$ różnice w wynikach analiz stateczności składa się wiele elementów. Jest to między innym podejście geologa bądź geotechnika, dobrane współczynniki obliczeniowe, rodzaj wybranej metody obliczeniowej. Największe znaczenie mają jednak przyjęte do modelu parametry obliczeniowe warstw gruntu. W opisywanym przypadku różnice te są szczególnie widoczne ze względu na różnice w wyznaczaniu parametrów wytrzymałościowych gruntu pochodzącego z koluwium.

Efektywne wartości kąta tarcia wewnętrznego są stosunkowo wysokie, nierzadko nawet kilkukrotnie większe niż całkowite. $W$ gruntach spoistych badanych metodą $C D$ oraz CU, gdy parametry wytrzymałościowe oblicza się ze wzoru Terzaghiego (1923), różnice tych wartości wzrastają wraz ze wzrostem stopnia plastyczności, tzn. w konsystencji zwartej różnice są nieznaczne, a w stanie plastycz- nym i miękkoplastycznym bardzo duże. W analizach stateczności w przypadku, gdy wartości kąta tarcia wewnętrznego przewyższają kąt zapadania stoku (skarpy), uzyskuje się względnie wysokie tj. bezpieczne wartości wskaźnika bezpieczeństwa. Wyniki analiz stateczności badanego na potrzeby artykułu osuwiska wykazały, że przyjęcie do obliczeń efektywnych wartości parametrów wytrzymałości na ścinanie, uzyskanych na próbkach po 24-godzinnej konsolidacji i ścinanych przy małej prędkości przyrastania naprężeń ścinających, wskazują nie tylko na stateczność skarpy, ale także na duży zapas jej bezpieczeństwa. Przyjmuje się, że skarpy o wskaźniku stateczności powyżej 1,5 są bezpieczne. W warunkach rzeczywistych przemieszczenia w obrębie koluwium opisywanego osuwiska obserwuje się już po 2-3 dniach intensywnych opadów.

Wyniki analiz, uzyskane dla tych samych próbek ścinanych bez konsolidacji przy szybkim przyrastaniu obciążeń, wskazują na znacznie mniejszy wskaźnik bezpieczeństwa. Zastosowanie do obliczeń parametrów efektywnych wydaje się być słuszne jedynie dla skarp dobrze odwodnionych, w których istnieje możliwość szybkiego rozproszenia przyrostów ciśnienia wód porowych. 


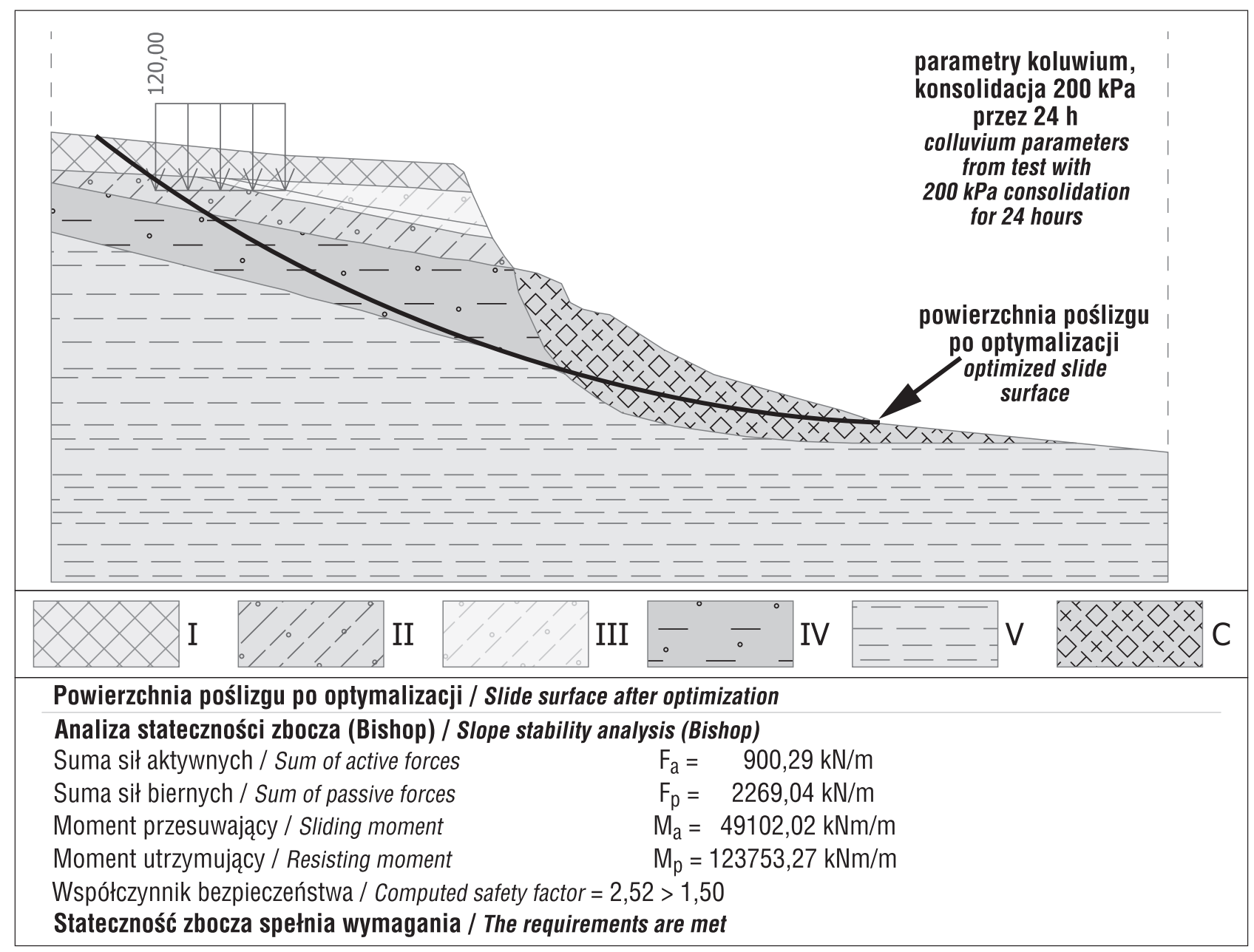

Ryc. 6. Analiza statecznści osuwiska w Kojszówce - parametry koluwium wyznaczone po 24-godzinnej konsolidacji przy naprężeniu konsolidacyjnym $200 \mathrm{kPa}$. Cyframi I-V zaznaczono numery warstw geotechnicznych

Fig. 6. Slope stability analysis of landslide in Kojszówka - colluvium parameters from test with $200 \mathrm{kPa}$ consolidation for 24 hours. Geotechnical layers are marked with numbers I-V

Warto również zauważyć, że nawet najbardziej zaawansowany program umożliwiający wykonywanie analiz stateczności jest tylko narzędziem, a jego wyników nie możemy brać za nieomylne. Każdorazowo wykonana analiza stateczności wymaga weryfikacji opartej na zdrowym rozsądku oraz doświadczeniu osoby biorącej odpowiedzialność za wyniki analiz.

Autorzy pragną złożyć serdeczne podziękowania recenzentom artykułu - dr. Piotrowi Neścierukowi i dr. Zbigniewowi Frankowskiemu - za cenne uwagi i sugestie, które korzystnie wpłynęły za końcową treść pracy.

\section{LITERATURA}

COULOMB CH. 1773 - Essai sur une application des regles des maximis et minimis a quelques problemes de statique relaifs a l'architecturc. Paris.

GLAZER Z. 1985 - Mechanika gruntów. Wydaw. Geol., Warszawa. KACZYŃSKI R. 1984 - Badania wytrzymałości na ścinanie wybranych gruntów spoistych. NOT Warszawa.

LAMBE T.W., WHITMAN R.V. 1977 - Mechanika gruntów. Arkady, Warszawa.
PIECZYRAK J. 2014 - Wprowadzenie do geotechniki. Dolnośląskie Wydawnictwo Edukacyjne, Wrocław.

PISARCZYK S. 1998 - Mechanika gruntów. Of. Wyd. PWr, Warszawa. PISARCZYK S. 2015 - Grunty nasypowe. Właściwości geotechniczne i metody ich badania. Of. Wyd. PWr., Warszawa.

PKN-CEN ISO/TS 17892-10. Badania geotechniczne. Badania laboratoryjne gruntów część 10 . Badania w aparacie bezpośredniego ścinania. PN-EN 1997-2: 2008 Eurokod 7. Projektowanie geotechniczne. Część 2: Rozpoznanie i badanie podłoża gruntowego rozdział 5.8 .

PN-EN ISO 14688. Rozpoznanie i badania geotechniczne. Oznaczanie i klasyfikowanie gruntów. Część 2: Zasady klasyfikowania.

TERZAGHI K., 1923 - Die Berechnung der Durchlässigkeitsziffer des Tones aus dem Verlauf der Spannungs-erscheinungen. Sitzungsberichte der Akademie der Wissenschaften mathematisch-naturwissenschaftliche Klasse. Abteilung 2A, 132, 105.

TERZAGHI K. 1936 - The shearing resistance of saturated soils and the angle between planes of shear. [W:] Casagrande A. et al. Proceedings of the International conference on soil mechanics and foundation engineering. Harvard University, 1: 54-56.

WIŁUN Z. 1976 - Zarys geotechniki. Wydawnictwa Komunikacji i Łączności, Warszawa.

WIŁUN Z. 2013 - Zarys geotechniki. Wydawnictwa Komunikacji i Łączności, Warszawa.

Praca wpłynęła do redakcji 27.11.2019 r.

Akceptowano do druku 14.02.2020 r. 